\title{
The Role of Stereotypes in the Creation of National Image: The Image of Croatia held by Japanese People
}

Preliminary communication__DOI 10.22522/cmr20200154_received on 27 September 2019 UDK: 316:338.48

659.122:323.2(497.5)

\section{Tanja Grmuša, PhD, Assistant Professor}

Marketing and Communication Department, Business School of Zagreb, Zagreb, Croatia.

E-mail: tanja.grmusa@pvzg.hr (corresponding author)

\section{Hazuki Mori, PhD, Assistant Professor}

Department of Indology and Far Eastern Studies, Faculty of Humanities and Social Sciences, University of Zagreb, Zagreb, Croatia.

E-mail: hazkim@gmail.com

\section{Abstract}

How do stereotypes work while national images are built? This is one of the major questions in our long-term research project. As the first step towards finding answers to this question, this paper explores Japanese stereotypes of Croatia as a case example through qualitative approaches. The main reasons Japanese stereotypes are discussed here are: 1) we believe that Japanese people do not have a strong bias toward Croatia, either positive or negative, and 2) we hope to somehow contribute to Croatian tourism strategies, which should be based on the creation of a good national image - Croatia can become a more popular destination for more Japanese people. One of the main objectives of this paper is to contribute to the Croatian tourism industry, as well as to research stereotypes and national branding based on these motives.

Keywords: national images, stereotypes, interculturalism, national branding, tourism strategies, destination marketing plans 


\section{Introduction}

How do stereotypes work while national images are built? This is one of the major questions in our long-term research project. However, to discuss this as a whole is beyond the scope of a brief paper. Therefore, as the first step, in this paper we would like to start examining how stereotypes are generated and how they have affected the creation of national image through a case example: descriptions of Croatia provided by Japanese people in various fields.

Croatia has not succeeded in making prospective profits from tourism (UNWTO, 2018) despite its rich natural and historical resources. Even though the Croatian people have debated on how to convey their country's good points to people from other cultural backgrounds, they have been unable to establish a national brand of Croatia, or even strategies for utilising its tourism resources. One of the greatest reasons for this might be 'stereotypes of Croatia' held not only by people from other cultural backgrounds, but by Croatians themselves.

In order to consider this matter, we would like to explore some stereotypes, beginning with an investigation of stereotypes of Croatia held by Japanese people. One of the main reasons why we begin the discussion with this case example is that we believe that Japanese people may not have a strong bias toward Croatia, either positive or negative. Another reason is that Croatia can become a more popular destination for more Japanese people.

Japan had the world's third largest GDP in 2018 (The World Bank, 2019). With its economic power, Japan could become a major economic partner to Croatia as a country whose citizens would visit Croatia more often (cf. Table 1) and thus contribute to Croatian economy through local spending. This would help Croatia to achieve its goal of increasing tourism outside of the summer season (which mainly targets European tourists currently). For instance, the total number of Japanese people who travelled abroad in 2018 was roughly 18.9 million. More than 1.25 million Japanese people travelled internationally every month (cf. Figure 1). 


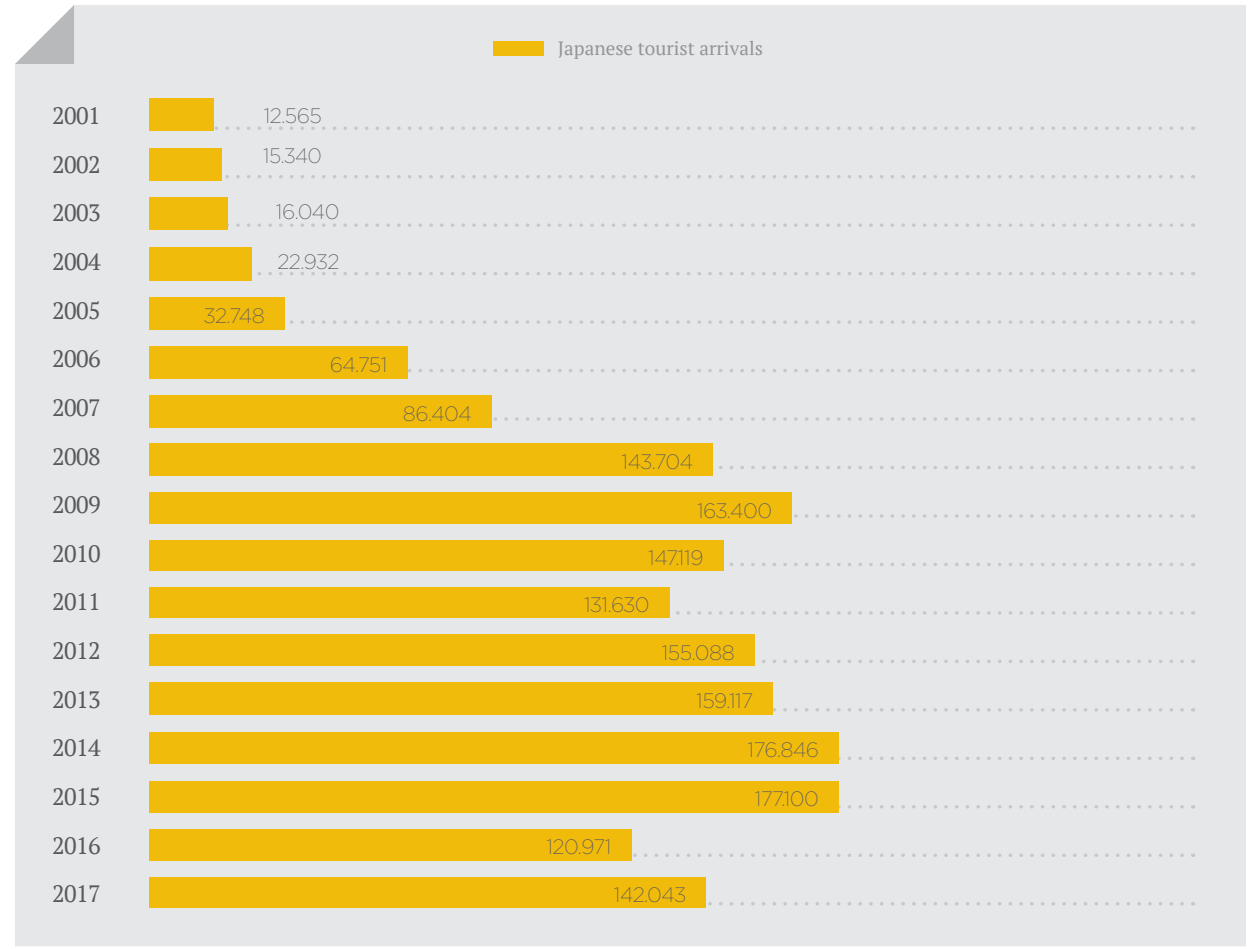

Figure 1. Japanese tourist arrivals in Croatia based on data collected from website of Japan Association of Travel Agents (Jata-net.or.jp, 2019)

Japan is also ranked second (Ipsos, 2018) on the Anholt Nation Brands Index (NBI). Japan can certainly serve as a good role model for Croatia in this respect by providing ideas on how to build a stronger national brand by learning from both positive and negative aspects of Japan's national branding, such as communications strategies for the upcoming 2020 Olympics intended to bring Japan closer to the rest of the world. (This topic cannot be discussed in this paper due to lack of space and we save the exploration of this for another time.) An additional motive for starting this project was the fact that the 25th anniversary of the establishment of diplomatic relations between Japan and Croatia (Hr.emb-japan. go.jp/hr, 2018) was celebrated in 2018-2019 (cf. Figure 2). 


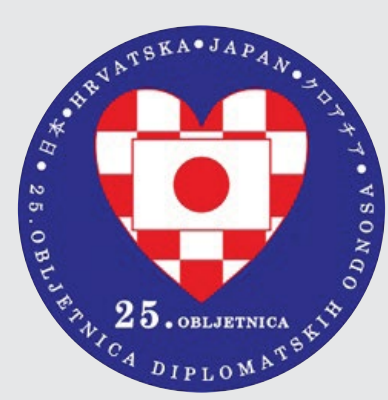

Figure 2. Logo for the 25th anniversary of diplomatic relations between Croatia and Japan, created by Embassy of Japan in Croatia (Hr.emb-japan.go.jp, 2018)

With these motives in mind, the first section describes how images and stereotypes of Croatia have either changed or not changed throughout the years, and what general images and stereotypes of Croatia are currently held, providing an overview of some key concepts for delving into national branding such as intercultural communication, stereotypes, communications strategy, etc. The second section presents current research outcomes.

\section{National Branding - Between the Desired Image and the Actual State}

\subsection{Intercultural Communication and Stereotypes}

Communicating with members of other cultures is often seen as communicating with the "other", with those different from ourselves, in which an attempt is made to interpret diversity simply through the existence of "we" and "I" cultures. While the "we" culture is known to be collectivist, aimed at building a group identity, the "I" culture is individualistic, placing the opinions and attitudes of the individual above the views of the group (cf. Čerepinko, 2012, p. 167). De Vito emphasises that cultural differences can be examined on several levels; a) individualism vs. collectivism, b) contextuality, c) the issue of power, d) masculinity - femininity, e) tolerance for differences, f) orientation towards the short- or long-term (cf. De Vito, 2013; De Vito, 2016).

Intercultural communication frequently sees stereotypes that represent the subjective experience of a person, nation, or state, on the basis of which a certain position can be 
taken (Labaš, Grmuša, 2011). Some concepts related to stereotypes are identity, image, and perception (Skoko, 2009). Image is the perception/experience an individual has of a person or object, which is often based on their own (acquired) opinions, beliefs, and attitudes (cf. Skoko, 2009, pp. 28-29). The process of image creation is very complex and is influenced by categories and symbols such as memory and persuasiveness in communication (cf. Skoko, 2009, p. 33). The transformation of national image is institutionally driven in some countries under the auspices of separate bodies/commissions, however, the image is still the responsibility of the country itself (cf. Skoko, 2009, p. 53). Analysing stereotypes that are conditioned by cultural heritage is increasingly the subject of psychological research, whereby established is a new methodological framework for research in this field. Instead of the current focus on cultural and national issues, David et al. (2018) focused on the study of the cognitive dimension of stereotypes. They sought to explore how methods, data collection, and the way that they are analysed affect the content of stereotypes. The results of their study confirmed that stereotypes proportion varies depending on the research methodology used: qualitative like a case study (structured or semi-structured interview or quantitative like a survey or content analysis). The psychological context has shown that the study of stereotypes relates not only to their presence in the cognitive spectrum, but also should have focused on their availability in collective memory of individuals and nations (cf. David et al. 2018, p. 389). Reliance on the psychological prism of stereotyping helps us to understand the effects of presenting and framing media representations of a particular groups (Giles, 2003), as well as their perception by the audience (Ramasubramanian, 2014).

\subsection{Transformation of the Croatian National Image}

The image of Croatia in previous state structures, especially during World War II, was either rated as unknown or accompanied by negative stereotypes, which also reflected on negative perceptions of the country by the international community. In communist times, it was common to obscure the national identity, which was interpreted as a threat to the political system of the time (Skoko, Miličević, Krešić, 2017, p. 82). With the emergence of new states in the early 1990s, new challenges began for Croatia in the form of repositioning itself on the international political scene. Promotional activities began in 1993 with the slogan "Croatia - a small country for a great holiday", followed by a redesign of its visual identity in 1997 and three international conferences in Dubrovnik (Hall, 1999, pp. 233-234). Later slogans such as "An Old Friend with a New Name”, “The Thousand 
Islands of the Croatian Adriatic", "Zagreb - the Heart of Croatia, the New European Metropolis", and "The Mediterranean as It Once Was" showed that Croatia was able to maintain its specificity through continuous promotion in creating its own image (Skoko et al., 2017, pp. 87-89). Finally, Croatia entered the EU in 2013 after decades of demanding negotiations, during which some negative stereotypes related to the Balkan countries still needed to be changed. Skoko et al. (2017) see numerous diplomatic failings in Croatia's EU accession process (Skoko, 2012), which, instead of promoting the image of a new member state, relied solely on bureaucratic language in transmitting European ideas and values. The greatest comparative advantages of Croatian tourism are its natural beauty, preserved cultural and historic heritage, and biodiversity; these are also the elements most commonly perceived by tourists according to previous studies (Michael, Miličević, Krešić, 2014 according to Skoko et al. 2017; Telišman-Košuta, 2017).

\subsection{Communications Strategies to Promote Croatia in International Markets}

National identity and image management is based on public relations strategies involving both domestic and international stakeholders, and the entire process must be well coordinated. The greatest challenges in the destination branding of Croatia are certainly the presentation of lesser-known regions and counties, the functioning of the Croatian National Tourist Board as an umbrella organization that coordinates all activities, and the establishment of a destination management organisation (cf. Telišman-Košuta, 2017, p. 71).

The history of national planning in Croatia in the tourism sector has been unsystematic and disorganised, which can be traced in several stages. The first tourism development strategy was adopted in 1993 by the Institute for Tourism during the Croatian War of Independence, which aimed to reposition the country's national identity and brand. The emphasis on natural beauty and tourism development was intended to improve Croatia's economic positioning, and this was followed by a long-term plan to develop Croatian tourism in 1998 (cf. Tomljenović, Ateljević, 2017, p. 22). Furthermore, in 2010, the Croatian Tourism Development Strategy was adopted, which emphasised the multiple contributions of tourism in the context of developing other industries. The greatest issues with all the adopted strategies lay in their feasibility and the lack of staff to implement them, which confirms that Croatian tourism is still underdeveloped in terms of its scope, quality, and creativity. The main outcome of this is that the tourist season has not yet 
been extended beyond the summer months (cf. Tomljenović, Ateljević, 2017, p. 23), a fact the authors attribute to the lack of a coordinated DMO system.

The key questions are - what do we want to be as an industry? How do we want to contribute to society and what do we want to be for our visitors? The answers to these questions represent the three pillars of the national tourism vision (cf. Tomljenović, Ateljević, 2017, p. 30).

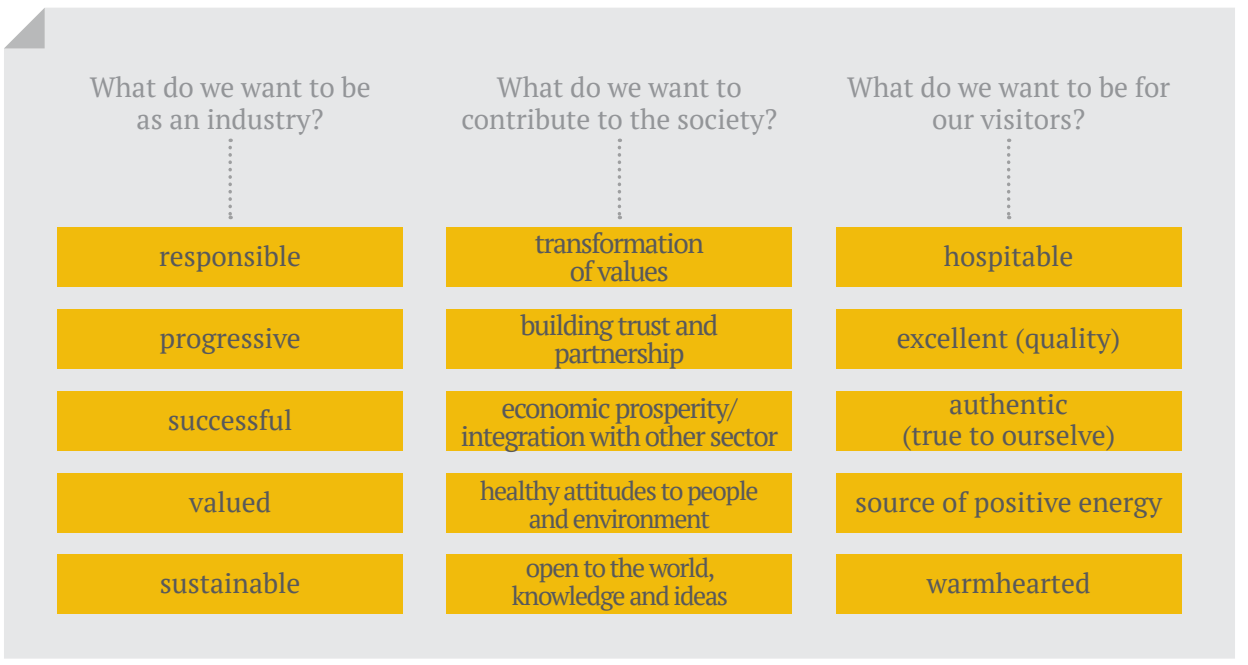

Figure 3. Three pillars of a national tourist vision (Tomljenović, Ateljević, 2017, p. 30)

Although tourism is one of the largest promoters of Croatia in the world, Skoko considers it insufficient in the context of international relations (cf. 2017, p. 26), adding that strategic communication is systematically lacking, trends are not followed, and the vision and mission of Croatia's tourism strategy are unclear. Croatia's forthcoming presidency of the European Council in early 2020 thus presents an opportunity Croatia should make the most of to strengthen its image in the EU.

The following questions thus arise: how do tourists from Eastern markets like Japan view Croatia? What kinds of experiences have they had with Croatia? How many images of Croatia held by Japanese people can be said to be based on their own real, personal experiences? 


\section{A Case Example - What Images of Croatia Do Japanese People Have?}

\subsection{Research Methods}

As our first effort to find answers to the questions mentioned above, a qualitative research has been conducted. A progress report of it can be found in this section. We have conducted both in-depth interviews with Japanese people (details to follow) and a descriptive case study (Wimmer Dominick, 2011; Berger, 2011) covering diverse subject matters. This methodology allows a broad approach to our research and the use of specific methods, which most often serve as a pilot project for further research (Tkalac Verčič, 2010; Wimmer, Dominick, 2011).

\subsubsection{In-depth Interview - Research Questions and Goals}

In-depth interviews were conducted in Japan and Croatia in May 2019 on a deliberate sample of 17 respondents of both genders and all ages. In order to provide as large a frame of research participants as possible, they have been divided into three categories:

1. respondents who have visited Croatia,

2. respondents who have never visited Croatia, but have certain images of Croatia, 3. respondents who have worked in the tourism sector.

More detailed information about the participants in the in-depth interviews can be found in the table below (cf. Table 1). The data was collected through field interviews with the respondents during the aforementioned period, during which the conversations were recorded. The data was subsequently transcribed, coded, and attributed to each respondent. Due to the extensiveness of the interviews and the limited scope of work, the most important points of their statements are cited on an as-needed basis. 


\begin{tabular}{|c|c|c|c|c|}
\hline \multicolumn{5}{|c|}{ INTERVIEWEES WHO HAVE BEEN TO CROATIA } \\
\hline \multirow{7}{*}{ A } & 1 & $71-80$ & male & pensioner \\
\hline & 2 & $71-80$ & male & pensioner \\
\hline & 3 & $41-50$ & male & company employee \\
\hline & 4 & $41-50$ & female & university professor \\
\hline & 5 & $41-50$ & male & company employee \\
\hline & 6 & $31-40$ & female & medical service worker \\
\hline & 7 & $21-30$ & female & company employee \\
\hline \multicolumn{5}{|c|}{ INTERVIEWEES WHO HAVE NEVER BEEN TO CROATIA } \\
\hline \multirow{8}{*}{ B } & 1 & $61-70$ & male & medical doctor \\
\hline & 2 & $51-60$ & female & postgraduate student \\
\hline & 3 & $41-50$ & female & company employee \\
\hline & 4 & $41-50$ & male & company employee \\
\hline & 5 & $41-50$ & male & company employee \\
\hline & 6 & $41-50$ & female & university teacher \\
\hline & 7 & $31-40$ & male & company employee \\
\hline & 8 & $31-40$ & female & postgraduate student \\
\hline \multicolumn{5}{|c|}{ INTERVIEWEES WHO HAVE WORKED IN THE TOURISM INDUSTRY } \\
\hline & 1 & $41-50$ & female & $\begin{array}{c}\text { between jobs } \\
\text { (worked in a travel agency) }\end{array}$ \\
\hline & 2 & $31-40$ & male & $\begin{array}{l}\text { company employee } \\
\text { (travel agency) }\end{array}$ \\
\hline
\end{tabular}


In order to reach to our current goals, the following research questions were asked first in the interviews:

G1: to explore Japanese people's images of Croatia

G2: to analyse Japanese people's experiences related to Croatia

G3: to figure out stereotypes related to Croatia held by Japanese people

G4: to determine possibilities to better promote Croatia in Japan

Accordingly, the following research questions were raised:

RQs1: What images of Croatia are held by Japanese people?

RQs2: What kind of experiences with Croatian people and Croatia have Japanese people had?

RQs3: What stereotypes related to Croatia are presented in promo materials and the Japanese media?

RQs4: How has the Croatian National Tourist Board promoted Croatia in Japan?

\subsubsection{Descriptive Case Study}

Relying on media can be the first step in exploring a destination for many people (Sulaiman, Wilson, 2019), since tourists want virtual experiences in addition to "classic" experiences. The structure of the message intended for the target group plays a significant role, since the description of the destination and its public presentation strongly influence its tourist appeal. This is a persuasive technique that seeks to encompass the understanding of the other, the authenticity and background of the tourist destination. The recognition of the tourist destination depends on many factors such as information, novelty, uniqueness, and the personal experiences of individuals/consumers (cf. Sulaiman, Wilson 2019, p. 22). In the descriptive case study, we examined various materials including descriptions of Croatia presented to Japanese people in their daily lives: tourist information (e.g. Croatian National Tourist Board brochures distributed in Japan, advertisements by tour companies, etc.), sports-related events, media coverage of Croatian athletes, TV programmes (e.g. serial dramas, travel programmes, documentaries, etc.), films, websites, blogs, content posted on social networks, etc. (Only those considered significant are included for reasons of space.) 


\subsection{Interpretation of research results}

\subsubsection{Promotion of Croatian National Tourist Board (CNTB) in Japan}

Since The Croatian government had set up a tourism promotion office in Tokyo in 2008, the office had engaged in a tourism promotion campaign and provide up-to-date information for visitors until the CNTB decided to close its doors to the publc in 2015.

As a director of the office of the time, Edouard Tripkovic Katayama mentions, most Japanese people did not know where Croatia was. Even if they knew anything about Croatia, that were a sort of stereotypes. Those of Croatia held by Japanese people in those days were: Croatia was "a dangerous country”, "a country in war”, "communist country”, and the like.

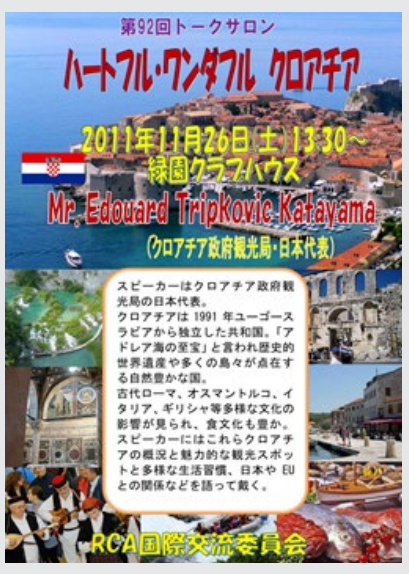

Figure 4. Flyer for an event to introduce Croatia, which was titled 'Heartful wonderful Croatia'. The event was held by Ryokuen-toshi Community Association International Exchange Committee, in Kanagawa prefecture, Japan in 2011 (Ryokuen.gr.jp, 2019)

The office strenuously carried out public relation activities with the catch phrase "Heartful Croatia" in order to break the stereotypes (Tripkovic Katayama, Edouard, Make a good choice on website of Japan Tourism Research \& Consulting Co. - Tourism.jp, 2016). It is safe to say that one reason for the increase of Japanese tourists to Croatia was that 
their activities bore fruits (Figure 4). However, the interviews we conducted provide insights into how Japanese people perceive Croatia. It might be said that Croatia is still an obscure country for Japanese people. Let us take a look at some comments made by our interviewees:

"When I told people around me about my travel plans to Croatia, I got anxious because they asked me 'Are there no problems travelling to a country that was at war?' or 'Isn't it a dangerous place?'” (interview participant A6)

"I heard of Croatia about 30 years ago through world history class. I became interested in the process of the collapse of Yugoslavia. I imagined Croatia as a poor socialist country in Central Europe. Then, I thought that it was a dangerous region because of how fierce the 'internal conflicts' were when the Yugoslavian team was disqualified at UEFA Euro 1992.” (interview participant A8)

“I haven't really seen many things related to Croatia. If I didn't have a friend living in the country, I would not get to know about it at all.” (interview participant A5)

"I hadn't found any information about tourism in Croatia. I feel like that I've seen more information since my friend moved to Croatia." (interview participant A3)

“I haven’t really seen anything related to Croatia lately.” (interview participant A4)

"I have not seen many advertisements for tourism in Croatia. Probably because I don't watch TV much. But I use the internet a lot... I seldom see this information on the web as well...” (interview participant B7)

The CNTB has also organized a workshops and presentations of the Croatian tourist offering in Japan (Embassy of the Republic of Croatia in Japan (Jp.mvep.hr, 2019). However, all of the interviewees and some Japanese people whom we engaged with in casual conversation, stated that they had never seen a brochure distributed by the CNTB in Japan (further research should take into account differences in the daily experiences of interviewees with regard to their place of residence).

At the same time, the state becomes an important subject and object of international relations, according to Skoko (cf. 2009), and emphasizes the role of public opinion in the process of image transformation. Transformation of the national image was a challenge for the former member states of the Communist Bloc, which successfully responded to it 
(such as Latvia, Croatia, Slovakia and Slovenia) (cf. Tench, Yeomans, 2006, p. 159 as cited in Skoko, 2009, p. 58). Furthermore, it emphasizes that public diplomacy is not only tasked with promoting government policy, but serves as an upgrade, and must therefore be strategically designed and planned (cf. 2009, p. 67). We would believe that it is necessary to consider the following points.

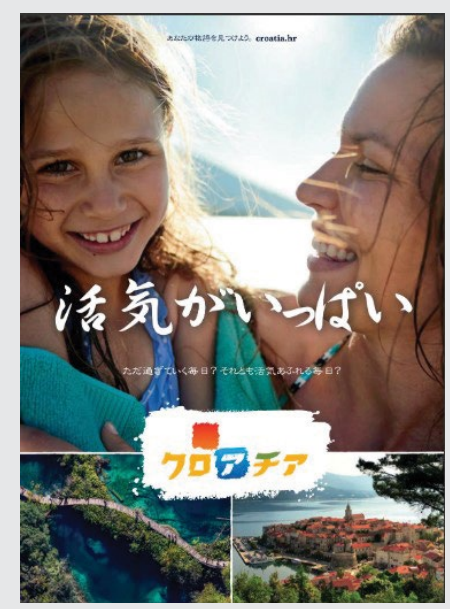

Figure 5. Pamphlet published by Croatian National Tourist Office in Japan in 2015, which contains 110 pages (Croatia.hr, 2018)

\subsubsection{Stereotypes and images related to Croatia in Japanese media}

Next, let us examine some specific examples of stereotypes and images of Croatia held by Japanese people through seeing things that appeared in Japanese media. When we asked Japanese people "what comes to your mind when you hear the name Croatia?" in our interviews, some of them, especially people around 30 years of age or over, would name Mirko Filipović.

“First, Mirko 'Cro Cop' came to mind... Actually, nothing else came to mind. Before

Croatia became known in Japan as it is now, I only knew that Mirko was called 'Cro Cop' because he had been a 'Croatian cop'...” (interview participant B5)

As we may see in the answer above, it can be said that Mirko Filipović was the first point of contact with Croatia for many Japanese people, especially in these generations. 
Some say that they were even introduced to the Croatian flag by seeing the shorts Mirko Filipović wore in matches, and that the term 'Croatia' reminded them of a red and white checkerboard pattern. This shows that sports and athletes are an important elements in establishing a national image. When Filipović announced his retirement from martial arts in March of this year, it hit the news in Japan. In much of the news, we have found the description of the reason why Mirko Filipović began training himself in martial arts with his words:

"In my mid-teens, while other boys in my age group were enthusiastic about football and suchlike, I devoted the whole time and energy only to strengthen my body out of my fear of and anger against war. I pledged that I would become strong to protect others. I didn't want anyone die" (cf. K-1kickone.com, 2019).

As we may see from this example, it can be said that Japanese people are still prone to associate Croatia with images of 'war' and its tragic consequence.

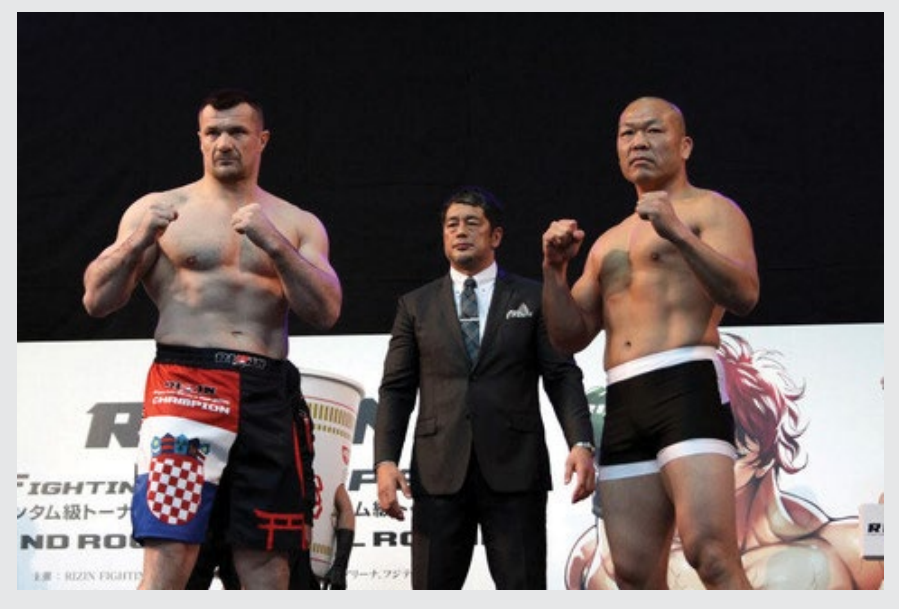

Figure 6. Mirko Filipović with a Japanese martial arts fighter (Datoukyoku.blog.jp, 2019)

Another example illustrating the fact that athletes play an important role in producing Croatia's national image in Japan is that of Luka Modrić. According to Croatian/Japanese guides for Japanese tourists, many Japanese tourists ask where they can buy replicas of 
Modrić's jersey during their stay in Croatia. Since Modrić has become popular in Japan not only due to his great skill as an athlete, but also due to his life story, including his experience in the war (which was introduced by the Japanese media during the 2018 World Cup). Here again, we may say that Japanese people have a sort of stereotype of Croatia which has been related to war. In addition, Japanese people have a tendency to prefer "tragic" stories to happy ones, and they sympathise more with heroes who overcome "tragedy" to achieve good results than with those who are "superheroes" from the moment they are born (Ishimoda, 1948). It might be considered that this tendency is one of the reasons why Japanese people are attracted to him and his home country Croatia.

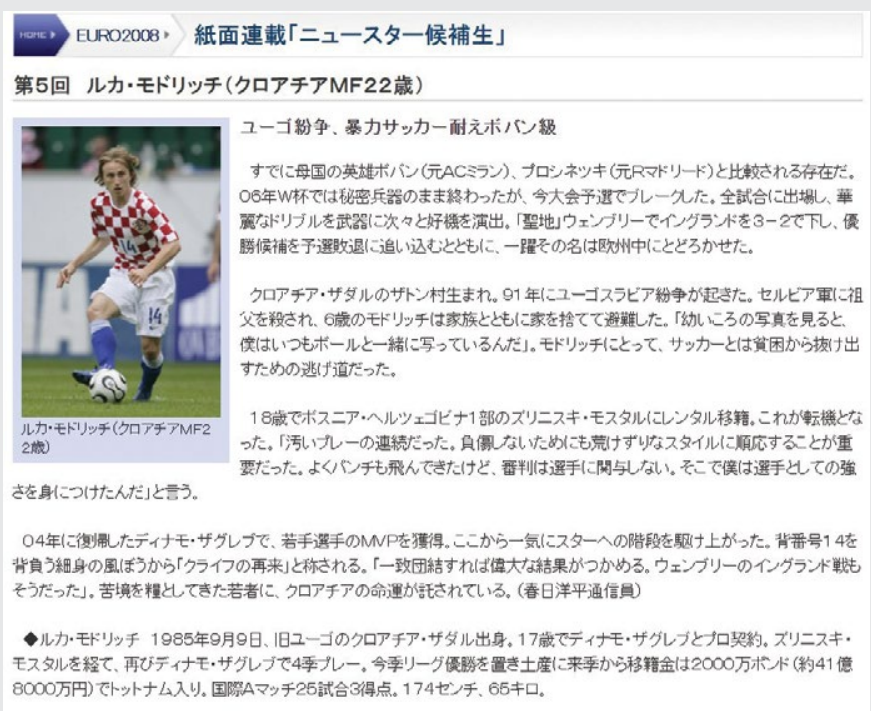

Figure 7. Japanese Internet article about Luka Modrić, mentioning his experience of war. Screen shot of a page by Nikkansports.com, 2019

Another media example is that of the popular TV drama Black Scandal, which featured a Croatian character named Sofia. It is interesting to note that the role of Sofia was not played by a Croatian actress, but rather by actress and fashion model Emma Jasmine, who was born to an Australian father and a Japanese mother. The show deals with the world of Japanese show business. Sofia takes advantage of her beauty and nice figure to become popular. 


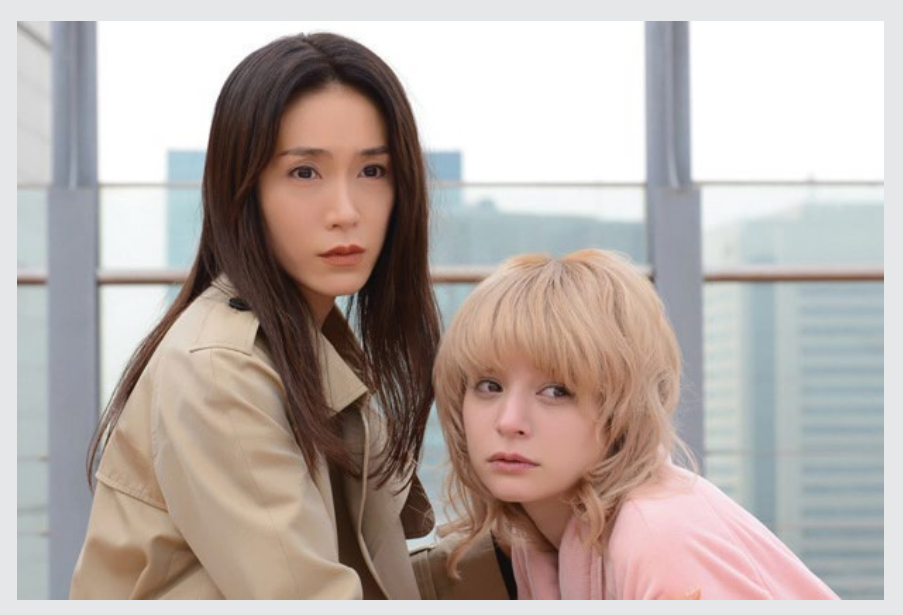

Figure 8. Black Scandal [2018] @Yomiuri Telecasting Corporation, https://www.ytv.co.jp/blackscandal/story/, 2019

However, she is selfish and has a short temper. When she is displeased, she becomes violent and aggressive easily and shouts "ne! ne!" to the staff of an entertainment company she belongs to. The reason Sofia works in Japan is that she believes she can earn money more easily there, which she intends to send to her mother and five younger siblings in Croatia. Her father abandoned the family to live with his mistress.

Interestingly, this type of character (a poor young foreign girl/boy working in Japan to send money home) in Japanese TV series or movies is often from South-East Asian countries such as the Philippines or Indonesia, since Japanese people often perceive these countries as "economic backwaters", underdeveloped, etc. It is hard to believe that Japanese people hold similar images of Croatia. Rather, the decision to make this character from Croatia may have been motivated by ambiguous images of Croatia tied to vague memories of the tragedy of the war.

These three examples above show how difficult breaking down the stereotypes is. Next, instances of media influence on Japanese people's images of Croatia are adduced.

"I saw a cave on a TV travel program and it made me want to travel to Croatia. So, I started collecting information on Croatia via the internet...then...I realized that I had 
confused Croatia with Slovenia... but I decided to visit Croatia regardless." (interview participant A6)

"Plitvice Lakes National Park appeared in a TV commercial for condominium apartments, and it interested me. I thought that Croatia would have beautiful nature." (interview participant C1)

"When I read an episode in a comic book in which the author illustrated her journey across the Aegean Sea to Croatia, I became interested in Croatia. This is how I first heard of Croatia.” (interview participant C2.)

The number of TV programmes or TV commercials related to Croatia seems to be smaller now than in recent years. If people happen to see something that appeals to them, they may become interested in Croatia. However, it must be emphasised that that they are unlikely to see things related to Croatia on TV by chance. TV shows or commercials first introduce Croatia's beautiful nature and lovely townscapes, followed by simple, but delicious Croatian food, dishes and wines, as well as occasionally its history and some traditional events. Some Japanese people say they are attracted to the beautiful coastal towns and nature of Croatia, however, as stated by one interviewee,

"I'm afraid that we can also enjoy these things in other, more famous places..." (interview participant B5).

However, some people have found particular personal reasons to want to visit Croatia. Some of these people have already travelled to other European countries and want to visit places unfamiliar to them and other Japanese people, while others have a strong interest in Croatia because of something they can experience only in Croatia. For instance, when asked "what comes to mind when you hear 'Croatia'?", many Japanese people name Dubrovnik as a setting of movies directed by Hayao Miyazaki.

"Dubrovnik came to mind. I think that Japanese people are familiar with this city because famous animated films produced in Japan are set in this city, and animation is one of the most influential Japanese cultural products." (interview participant A1)

"Movies produced by Studio Ghibli remind me of the beautiful landscapes of Croatia." (interview participant A6)

"When I heard that Dubrovnik was used as a setting for Kiki's Delivery Service, I became interested in Croatia and gathered information on it." (interview participant B8) 
Some Japanese people even visited Dubrovnik while dressed as Kiki, the protagonist of Kiki's Delivery Service, directed by Hayao Miyazaki (1989). This leads to the hypothesis that some Japanese people have a strong interest in Croatia because of things they can experience only in Croatia. Other examples of the same points are: the increasing number of young Japanese people who are interested in enormous monuments built during the former Yugoslavia; study tours conducted by instructors at Japanese universities or high schools in which they see the history of Croatia in Kumrovec; traces of war in Vukovar and Karlovac (there are arguments both for and against war tourism - the details shall be left to future discussion), etc.

Additionally, combining things available in Croatia with things Japanese people love and/ or are proud of, such as animated film, could help increase Japanese interest in Croatia and build a positive image of Croatia in Japan. This is one example in which interculturalism functions well.

\subsubsection{Japanese People's Experiences Related to Croatia}

As stated before, although it would be difficult for us to wreck our stereotypes of other nations, no explanation is necessary about the fact that there would be possibility for it when we visit the nations and see what they are like really. However, we cite some comments of interviewees who have been to Croatia so as to illustrate how their stereotypes were broken and the images of Croatia changed after their visit to Croatia.

"Before I visited Croatia, Croatia seemed to me like a part of a region 'behind the iron curtain', and I didn't have any clear images of Croatia. After my visit, I was surprised that Zagreb was so similar to Vienna in people's looks, the atmosphere of the city, and so on. After I heard that Croatia has been influenced by the cultures of neighbouring countries, I thought the nation's individuality and originality could lie in this fact itself." (interview participant A2)

"I got to know Croatia during the time of the civil war in Yugoslavia. I watched TV news about the wars of independence there. Later, I learned that Croatia had become independent when a Croatian pianist came to Japan. I was concerned with the post-war situation in the country. Therefore, before I visited Croatia, I had worried that Croatian people were cold like Hungarians and Czechs were (I had experienced that when I had visited the countries), however, it was reassuring to know that Croatian people were kind and cheerful." (interview participant A4) 
"Before I visited Croatia, I did not know Croatia well. I just had sort of gloomy images that had been commonly held in Japan toward former Yugoslavian countries. However, after my visit, I got the impression that Croatia is not 'gloomy' but a nice country where many cheerful and kind people live." (interview participant A7)

The point is, needless to say again though, how to increase Japanese visitors to the country. To bring up effective strategies for it is one of our motivations in carrying out our research project, as previously mentioned. This will also be examined in future papers we will publish.

\subsubsection{Stereotypes and Images of 'Croatia' Held by Japanese People}

In this paper, we showed some examples of stereotypes and images of Croatia that Japanese people have. Since not all of the responses by interviewees and information we gathered from various materials could be introduced due to space constraints, we will provide a summary of our findings here. They have not provided a wide variety of responses to questions related to their images of Croatia. They described Croatia as:

- a country with rich natural surroundings (especially a beautiful coastline)

- a country with beautiful and historic townscapes (most mentioned Dubrovnik)

- a country that has provided the setting for famous movies

- a country that is home to great athletes

- a country that was part of the former Yugoslavia

- a former socialist country

- a country with security concerns

- a "tragic" country: war and its aftermath, economic instability.

We plan to conduct interviews with more people to gather more material and delve further into how Japanese people perceive Croatia, as well as into how this image has been established. 


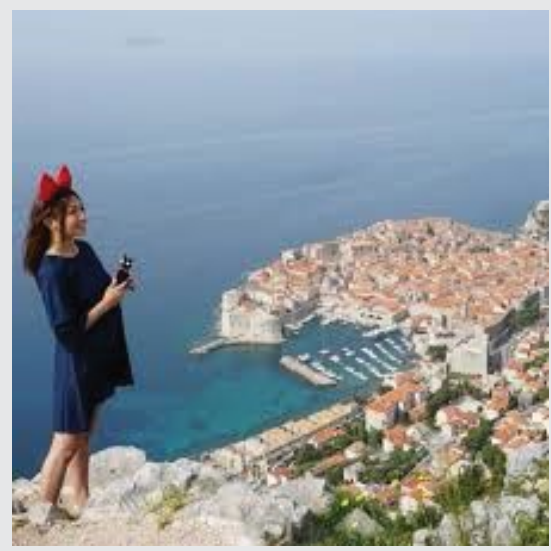

Figure 8. A Japanese girl cosplayin as Kiki in Kiki's Delivery Service. Photo by Ichihara Ayaka. Screenshot of a page on pikdo.net, 2019.

\section{Closing remarks}

It seems reasonable to conclude that the national images of Croatia held by many Japanese people remain vague. Even though some people know about Croatia, images about Croatia that they have are fragmentary in many instances. Many of the fragmentary images can be thought as stereotypical ones. We became even more keenly aware how strongly stereotypes affect national image building. This research has provided insight into the situation on the ground. The results cannot be generalised due to the small sample, however, they should be taken as an indicator and as impetus for further research. It would be interesting to contrast the Japanese view of Croatian people and Croatia to the images Croatian people have of themselves, as well as to compare the national branding processes in Croatia and Japan. These issues will be examined in our future research. 


\section{Reference List}

- Berger, A. A. (2011). Media and Communication Research Methods: An Introduction to Qualitative and Quantitative Aproaches. Thousand Oaks: SAGE.

- Čerepinko, D. (2012). Komunikologija: kratki pregled najvažnijih teorija, pojmova i principa. Varaždin: Veleučilište u Varaždinu.

- David, D., Bizo, A., Cimpean, A. I., Oltean, H., Cardos, R., Soflau, R., Negut, A. (2018). The effect of research method type on stereotypes' content: A brief research report. The Journal of Social Psychology, 158 (3) 379-392.

- De Vito, J. (2013, 2016). The Interpersonal Communication Book (13th Edition - 14th Edition). Boston: Pearson.

- Embassy of the Republic of Croatia in Japan (2019). Retrieved from: http://jp.mvep.hr/en/news/presentation-of-croatiantourism-in-japan,46766.html. July 5, 2019.

- Giles, D. (2003). Media Psychology. Mahwah, New Jersey London: LEA.

- Hall, D. (1999). Destination branding, niche marketing and national image projection in Central and Eastern Europe. Journal of Vaction Marketing, 5 (3), 227-237.

- Hr.emb-japan.go.jp/hr (2018). Retrieved from: https://www.hr.emb-japan.go.jp/hr/2018/bilater-2018-02-press.html. July 5, 2019.

- Ipsos (2018). Retrieved from: https://www.ipsos.com/en-us/news-polls/Nation-Brands-Index-2018. July 5, 2019.

- Ishimoda, S. (1948). Kodai kizoku no eiyu jidai (Heroic Age of ancient heroes). Iwanami Shoten, Publishers.

- Jameson, D. A. (2007). Reconceptualizing cultural identity and its role in intercultural business communication. Journal of Business Communication, 44 (3), 199-235.

- K-1kickone.com (2019). Retrieved from: https://k-1kickone.com/mirko-cro-cop-mma-kick-boxing-3188/. July 5, 2019.

- Labaš, D., Grmuša, T. (2011). Istinitost i objektivnost u informaciji i društveno štetne komunikacijske forme. Kroatologija, 2 (2), 87-122.

- Ramasubramanian, S., Murphy, C. J. (2014). Experimental Studies of Media Stereotyping Effects. In: Murray Webster, Jr., Jane Sell (Eds.), Laboratory Experiments in the Social Sciences - 2nd Edition (pp. 385-402). New York: Elsevier.

- Skoko, B. (2009). Država kao brend. Upravljanje nacionalnim identitetom. Zagreb: Matica hrvatska.

- Skoko, B. (2017). Communication Strategies and Branding Attempts of Selected Countries Created upon the Disintegration of the Former Yugoslavia. Sociologija i prostor, 55 (207 (1)), 5-31.

- Skoko, B., Miličević, K., Krešić, D. (2017). The Influence of Political Factors in Fashioning Destination Image. In: Larry Dwyer, Renata Tomljenović, Sanda Čorak (Eds.), Evolution of Destination Planning and Strategy: The Rise of Tourism in Croatia (pp. 79-98). Cham: The Palgrave Macmillan.

- Sulaiman, M. Z., Wilson, R. (2019). Translation and Tourism. Strategies for Effective Cross-Cultural Promotion. Gateway East Singapore: Springer.

- Telišman-Košuta, N. (2017). Shaping Destination Identity: Challenges of Branding Croatia. In: Larry Dwyer, Renata Tomljenović, Sanda Čorak (Eds.), Evolution of Destination Planning and Strategy: The Rise of Tourism in Croatia (pp. 67-78). Cham: The Palgrave Macmillan.

- The World Bank (2019). Retrieved from: https://data.worldbank.org/indicator/NY.GDP.MKTP.CD?most_recent_value_desc=true. July 5, 2019.

- Tomljenović, R., Ateljević, I. (2017). Cratfing a National Value-Driven Tourism Vision. In: Larry Dwyer, Renata Tomljenović, Sanda Čorak (Eds.), Evolution of Destination Planning and Strategy: The Rise of Tourism in Croatia (pp. 15-36). Cham: The Palgrave Macmillan.

- Tripkovic Katayama, E. (2016). Make a good choice on website of Japan Tourism Research \& Consulting Co. Retrieved from: https://www.tourism.jp/tourism-database/column/2016/07/croatia-tourism/. July 5, 2019.

- UNWTO (2018). Tourism Highlights. 


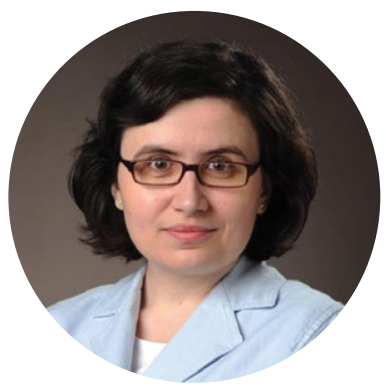

\section{Tanja Grmuša}

Tanja Grmuša is an assistant professor and senior lecturer in several undergraduate and graduate study programmes at the Zagreb School of Business. Since 2018, she has served as head of the Marketing and Communication Department. She teaches communication and business courses, and her research interests are related to communication studies, intercultural communicaton, media management, journalistic practice, and mass media impact. She is a collaborator at the Department of Communication Studies at the University Department of Croatian Studies, University of Zagreb.

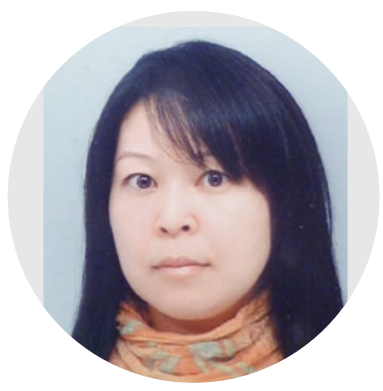

\section{Hazuki Mori}

Hazuki Mori is an assistant professor of Japanese Studies in the Department of Indology and Far Eastern Studies at the Faculty of Humanities and Social Sciences, University of Zagreb, where she has been a faculty member since 2010. Since 2018, she has served as the course chair. She received her $\mathrm{PhD}$ in Comparative Culture from the International Christian University in 2006. Her research interests lie mainly in areas related to religious phenomena in modern Japan and intercultural communication. 